\title{
Tourism Development in Upper Manang Valley of Annapurna Region
}

\author{
Bhim P. Subedi \& Prem Sagar Chapagain \\ bhim.subedi@gmail.com \\ ps.chapagain@gmail.com
}

\section{The Context}

People have traveled throughout history as they have moved from one place to another for various reasons. However, as a business and as guided by individual and group's voluntary activity, it flourished after the second half of the $20^{\text {th }}$ century, especially after the Second World War. Nepal followed a similar pattern as it was opened for outsiders only after 1950. Since then Nepal's natural beauty within various ecological zones and its rich cultural heritage have attracted large number of tourists annually from around the world and particularly from Western Europe.

The Annapurna Region is one of the notable tourist destinations, especially for trekking tourists. The region lies in the north-western part of Nepal. Popularly known as the Annapurna Trekking Route (Annapurna Circuit) boasting/ comprising some of the world's highest peaks of above 8,000 m elevation and the world's deepest valley, the Kali Gandaki Valley, it has attracted trekkers from many countries since the late 1980s in particular and since the 1970s in general (see Ives, 2006). Ecologically, the region comprises two high mountain districts and three hill districts. The region has unique ecological and cultural diversity. Such features include diverse climates, i.e. subtropical to alpine and diverse landscapes supporting 22 different forest types with 1,140 plant species, 21 species of amphibians, 32 species of reptiles, 478 bird species and 101 different mammals (KMTNC, 1997). In addition, its cultural diversity is demonstrated in its accommodation of people of different castes and ethnic groups such as Brahman, Chhetri, Gurung, Magar, Thakali, Tibetan and many occupational groups plus their own cultural and religious patterns and expressions. Moreover, the Annapurna Region has also been noted for its innovative work as early as in the 1980s in terms of participation of local community in activities and decisionmaking regarding tourism activities (see Sharma, 1989).

This paper discusses development and salient features of tourism in the Upper Manang Valley of the Annapurna Region. Though evidences of foreigners visiting Upper Manang date back to early decades of the $20^{\text {th }}$ century (see Kawakita, 
1957), it is only after 1970 that this valley became notable for tourists. This valley is part of the Annapurna Circuit and its tourism flourished especially after the initiation of the Annapurna Conservation Area Project (ACAP) in 1986. The main idea behind this is to conserve the unique diversity of the region while enhancing the livelihood of the people. Since its establishment, the project has implemented various programs related to agriculture, income generation, education and enterprise development so that the local people cooperate and feel the need of conservation for sustainable development. As the number of tourists have been increasing over time, it has been a challenge to protect the environment and to raise the living standards of the people.

\section{Data and Methods}

Three main sources of data have been used in this paper. Firstly, for discussion on the general trend of tourist arrival in the country and in the Annapurna Region, the statistics available from the Ministry of Tourism and Civil Aviation have been utilized. This also includes data collected from the local office of ACAP in Manang, the largest and main settlement in Upper Manang. Data available from the local office particularly relates to the monthly flow of tourists in this area. Secondly, for specific data at a local level, records available from Humde Police Post have been utilized. The Police Check Post keeps the records of all visitors passing through the post. The visitors' passport details including nationalities, sex and age are recorded at the minimum. Such records are not easily accessible to the commoners. We were able to collect such information through prolonged stay in their office premises. Thirdly, the author collected information about the existing hotels and their growth over the years in seven settlements of the Upper Manang Valley. Short interviews were also conducted with the hotel owners and some workers on case by case basis.

\section{Organization of the Paper}

The paper is organized into four sections. The first section provides context and objective of the paper. It also briefly notes what kind of data has been utilized plus the methods of data collection. The second section describes the development of trekking tourism in the Upper Manang Valley beginning with the development of trekking tourism in general. It also discusses seasonality of the flow of tourists there. The third section presents some demographic characteristics of tourists visiting this area. The fourth section concludes the paper with a glimpse of the outlook of tourism in this area.

\section{Trekking Tourism in Nepal}

Nepal is known for its natural and cultural diversity within its short northsouth territorial extent. With the opening of the country for the foreigners in 1950 , trekking tourism began to take shape. However, the number of visitors 
were limited before 1980. Despite some annual fluctuations, nevertheless, the number of West Europeans, North Americans and Asians visiting Nepal gradually increased. For example, the total number of tourists visiting Nepal in 1962 was 6,179 which increased to 45,970 in 1970, 156,123 in 1978 and 383,926 in 2006 (MCTCA, 2006). With the rising number of tourists, the number of trekkers also increased gradually. The total number of trekkers was only 556 in 1970, which went up to 27,460 in 1980, 61,471 in 1990 and 118,414 in 2000. Post 2000, the number of trekkers decreased due to conflict in the country. It was only after the peace negotiation in 2005 that trekking tourism witnessed its revival.

There are many trekking routes in the country that attract foreigners. Three routes, namely Annapurna, Everest and Langtang cover about 95 percent of the trekkers visiting the country. Again, of the three routes, the Annapurna Circuit is the most common route capturing about 60 percent of the total trekkers. Everest stands second with its share of total trekkers in the country fluctuating roughly between 20 to 30 percent. Likewise, Langtang ranks third with its share of 9 to14 percent during normal years (Table 1).

\begin{tabular}{|c|c|c|c|c|}
\hline \multirow{2}{*}{ Year } & \multicolumn{3}{|c|}{ Trekking Area } & \multirow{2}{*}{$\begin{array}{l}\text { Total number of } \\
\text { trekkers in Nepal }\end{array}$} \\
\hline & Annapurna & Everest & Langtang & \\
\hline 1970 & - & - & - & 556 \\
\hline 1980 & 52.19 & 21.25 & 14.98 & 27,460 \\
\hline 1985 & 57.93 & 25.50 & 14.08 & 32,730 \\
\hline 1990 & 59.15 & 18.41 & 12.73 & 61,472 \\
\hline 1995 & 59.45 & 17.83 & 10.02 & 84,120 \\
\hline 2000 & 64.53 & 22.53 & 9.22 & 118,414 \\
\hline 2001 & 65.22 & 22.00 & 9.14 & 100,138 \\
\hline 2002 & 64.79 & 23.44 & 8.04 & 59,644 \\
\hline 2003 & 61.88 & 28.62 & 4.75 & 65,721 \\
\hline 2004 & 60.98 & 28.87 & 4.35 & 69,442 \\
\hline 2005 & 58.91 & 31.75 & 4.45 & 61,488 \\
\hline 2006 & 56.63 & 30.92 & 6.82 & 66,931 \\
\hline
\end{tabular}

Table 1: Trekkers by major trekking route in Nepal (in percent)

Source: MoTCA, 2006.

As noted earlier, the number of trekkers went up since 1980 and reached its peak in 2000. From then onwards, the number spiralled down, reaching its lowest in 2005. The decrease in the flow can be attributed to the security concerns among visitors since these were the peak years of conflict and political unrest in Nepal. 


\section{The Dawn of Tourism in Manang}

Upper Manang is a part of the Annapurna Circuit. The whole district lies within the ACAP. Tourism in Manang started with the opening of the district for tourism in 1977 (Watkins, 1996; Koirala, 1981). The development of tourism is closely related with the entrepreneurship development such as trade, migration and tourism in the district. The local people of Manang have a very long history of their engagement in trade within and outside the country. Their visits to different parts of the subcontinent, South East Asia and Indo China have been recorded earlier (van Spengen, 1987). During the course of carrying out their business and procuring livelihood, they have long been engaged in various forms of mobility (Subedi, 2007). Their external mobility came to the forefront after they were provided special privileges in 1732, which continued till 1976. By 1980, not only had external trade become competitive, their special privilege had to be discontinued by the government because of parallel demands from other communities in the country. In such a competitive external trade-business it was not easy for many small-scale Manangi businessmen to thrive as in the past. Amidst these, Upper Manang was opened up for trekking and thus, some of the entrepreneurs with their skill and funds accrued during external trades found an avenue to carry on hotel management and other tourism-related activities back in Upper Manang. Moreover, the government's decision to include the entire district as part of the ACAP in 1984 further reinforced the prospect of tourism development in this area.

Upper Manang is a very pleasant valley. Inhabited by Manangis there are seven major settlements (Figure 1). Pisang is taken as the lowermost settlement of Upper Manag and the naming itself in Nyshang dialect reflects this. Likewise, Khangsar is the uppermost settlement and is located on the way and close to Tilicho Lake. These seven settlements of the valley together share more than 50 percent of the population of Manang district. The local people of the valley are believed to have migrated from different parts of Tibet long ago. The valley itself is characterized by physiographical diversity - from river basins to mountain peaks above $7,000 \mathrm{~m}$, bio-diversity and offers unique Tibetan culture and localized agro-pastoral economy.

\section{The Development of Trekking Tourism in Upper Manang}

Data on the number of tourists visiting the valley is officially available since 1999. However,

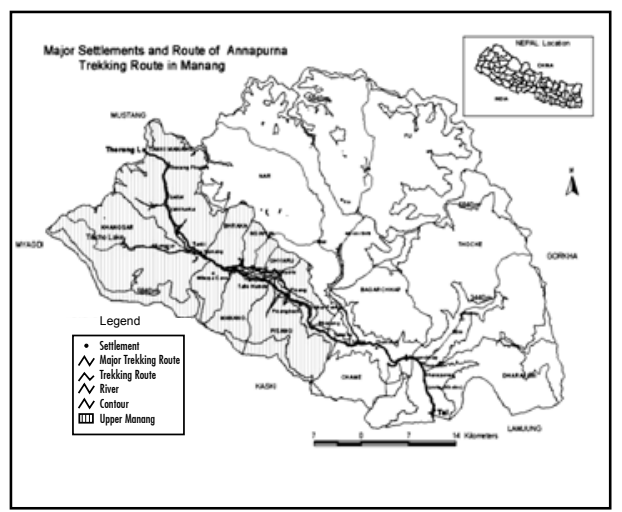

Figure 1: Major settlements and route of Annapurna Circuit in Manang 
Gurung (1995) has somehow managed to obtain earlier data on tourist arrival there from $1987 / 88$ to $1993 / 94$. Accordingly, a total of 5,816 tourists visited the valley in $1987 / 88$. The number went down to 5,233 in 1990/91 but climbed back to 5,895 in 1993/94. Not all the tourists of the Annapurna Trekking Route visit Manang as the route consists of Jomsom, Manang and Ghorepani. Out of the total tourists in the Annapurna Circuit, about one-fourth trek via Manang. According to National Trust for Nature Conservation (NTNC), local office in Manang, some 11,234 tourists visited Upper Manang in 1999. The number of trekkers increased to 13,920 by 2001 (Table 2 ).

\begin{tabular}{|c|c|c|c|c|c|c|c|c|c|c|}
\hline \multicolumn{2}{|c|}{ Months } & \multicolumn{9}{|c|}{ Number of tourists by year } \\
\hline & & 1999 & 2000 & 2001 & 2002 & 2003 & 2004 & 2005 & 2006 & 2007 \\
\hline January & & 58 & 120 & 176 & 79 & 104 & 112 & 93 & 137 & 116 \\
\hline February & & 379 & 307 & 484 & 294 & 269 & 313 & 89 & 177 & 270 \\
\hline March & & 1469 & 1669 & 1980 & 1386 & 1552 & 1499 & 1081 & 1063 & 1485 \\
\hline April & & 1668 & 1126 & 2453 & 1476 & 1629 & 1771 & 1038 & 806 & 2229 \\
\hline May & & 427 & 179 & 731 & 433 & 601 & 423 & 394 & 316 & 674 \\
\hline June & & 139 & 132 & 74 & 88 & 122 & 65 & 107 & 64 & 136 \\
\hline July & & 284 & 239 & 181 & 177 & 119 & 109 & 104 & 68 & 175 \\
\hline August & & 197 & 247 & 207 & 107 & 165 & 183 & 172 & 207 & 300 \\
\hline Septembe & & 1150 & 1367 & 1305 & 777 & 685 & 650 & 859 & 853 & 1250 \\
\hline October & & 3362 & 4334 & 3832 & 3060 & 3504 & 3339 & 3627 & 3627 & 4810 \\
\hline November & & 1841 & 2697 & 2222 & 1660 & 2029 & 1810 & 1720 & 1780 & 2339 \\
\hline December & & 260 & 306 & 275 & 304 & 357 & 252 & 306 & 262 & 408 \\
\hline & Total & 11234 & 12777 & 13920 & 9841 & 11136 & 10526 & 9590 & 9360 & 14192 \\
\hline Change & No & & 1543 & 1143 & -4079 & 1295 & -610 & -936 & -230 & 4832 \\
\hline & $\%$ & & 14 & 9 & -29 & 13 & -5 & -9 & -2 & 52 \\
\hline
\end{tabular}

Table 2: Number of tourist arrival in Upper Manang

Note: The year 1999 has been taken as the base year.

Source: ACAP's local office in Manang.

From 2002 to 2006, the number of tourists visiting the valley decreased. The annual flow figure of about 14,000 went down to less than 10,000 in 2002 . This figure increased to 11,000 the following year but again the downward spiral started, reaching the lowest in 2006. This decrease is not unique to Upper Manang but a common feature of Nepal as a whole. During these years, the total trekkers in the three major routes, namely Annapurna, Everest and Langtang decreased drastically from some 100,000 in 2001 to 67,000 in 2006. This being a reflection of the conflict, the figure increased after the Comprehensive Peace Accord between the government and the Maoist rebels in 2005 . The number of trekkers in Upper Manang reached more than 14,192 in 2007, the highest over the last nine years. 
Since 1999, despite slowdown and fluctuations, the annual figure of trekkers visiting this valley did not go down from 9,300. This is a sizeable number. These trekkers need accommodation and other services. As a result, with the increase in number of tourists, it was imperative that the number of hotels in the valley also went up (Figure 2). According to Cooke (1985), in 1985 there were only five hotels in Manang village two of which were under construction. By 1990, however, there were 19 hotels in different villages in the valley. From 1990 to 2000, a total of 20 new hotels were added. Most of these additions took place in Manang village (including Tanki-Manang) and Humde. After 2000, 19 hotels were newly opened. The villages of Khangsar, Manang and Ngawal had the most additions in their total number of hotels after post 2000.

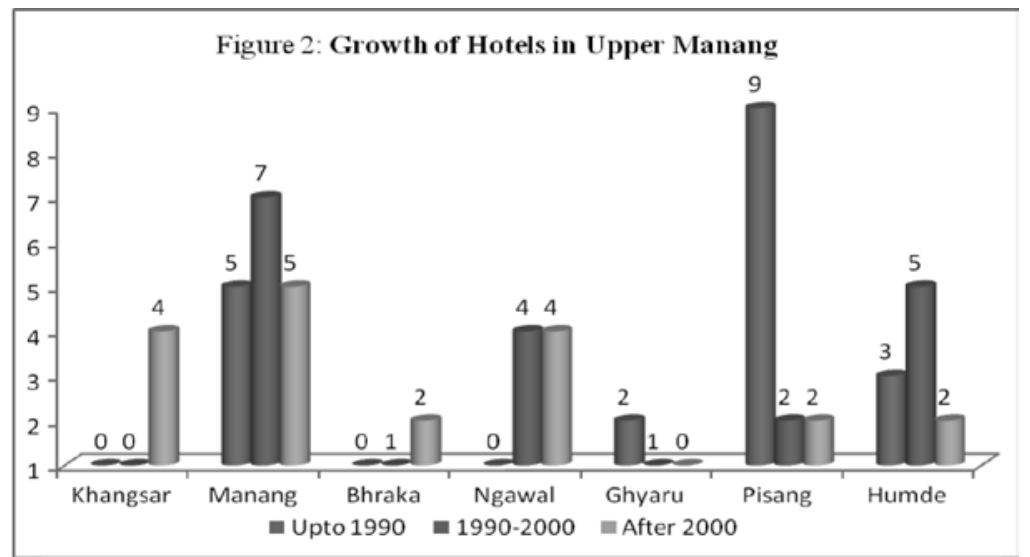

Source: Subedi, 2007.

In general, the largest numbers of hotels were opened in the settlements along the main trekking route such as Manang, Pisang and Humde. The off-route villages such as Ghyaru, Ngawal and Khangsar have fewer hotels. In the case of Khangsar, only those tourists trekking to the Tilicho Lake pass through the village and such tourists are very few in number.

Manang Village is the main settlement of the valley, not only from the present state of tourism development but also from the historical point of view. Manang village is epicenter of all social, political, cultural and administrative activities in the valley. The Gangapurna mountain peak and the Gangapurna Glacier are very close to Manang village. Also available in Manang village are cultural museum, movie theater, restaurants and other recreational facilities. The hotel owners in Manang sometime refer to this village functioning as Thamel of Kathmandu for tourists visiting this area. It is the little Thamel just beyond the Annapurna Range in the Central Himalaya.

Table 3 provides the present distribution of hotels in various settlements. Of all the settlements, Manang has the largest number of hotels. This is also the largest 
settlement of the valley. Pisang ranks second in its share of total number of hotels in the valley. Bhraka, Ghyaru and Khangsar have lower number of hotels. While Bhraka is very close to Manang, the main village of the valley, Ghyaru and Khangsar are primarily off-route villages.

\begin{tabular}{|c|c|c|}
\hline \multirow[t]{2}{*}{ Village/Settlement } & \multicolumn{2}{|c|}{ Distribution of Hotels } \\
\hline & Number & Percent \\
\hline Khangsar & 4 & 6.9 \\
\hline Manang & 17 & 29.3 \\
\hline Bhraka & 3 & 5.2 \\
\hline Ngawal & 8 & 13.8 \\
\hline Ghyaru & 3 & 5.2 \\
\hline Pisang & 13 & 22.4 \\
\hline Humde & 10 & 17.2 \\
\hline Total & 58 & 100 \\
\hline
\end{tabular}

Table 3: Distribution of hotels in Upper Manang by village/settlement, 2007

Source: Field Survey, 2006.

There are at least three interesting and notable features of tourism development in Upper Manang. Firstly, the growth pattern of hotels in Upper Manang in the late 1980s and early 1990s reflects a parallel with the development of touristoriented (budget) hotels in Kathmandu, particularly in Thamel and Jhonchhe (see Moromoto, 2003). For example, in Thamel there were only seven hotels in 1970 but the number increased to 143 by 1997 . Of the 143 hotels, the owners of 38 or 26.6 percent were from outside Kathmandu. Likewise, of the 38 owners from outside Kathmandu, 26 hoteliers or 68.4 percent were Gurungs. Furthermore, among the 26 Gurungs (hotel owners), 22 or 84.6 percent were Gurungs from Upper Manang. By 1997, Gurungs from Upper Manang had become the second largest group of hotel owners at Thamel in Kathmandu (Ibid, 2003).

Secondly, all the hotel owners are from Upper Manang or are Manangis. Outsiders are not allowed to run such businesses. Even in case of the in-laws, the entire community is very particular, and if any, they are exceptions. They are proud of running the tourism business in their native land and express that such a business run by the natives further reinforces their bond with the land and their identity. Thirdly, almost all big hotels have links with hotels in Kathmandu that are run by their relatives or at times by themselves. The skilled human resource for the hotel business is hired from Kathmandu, whereas all family members participate in tourism activities. Meanwhile the labor demand in agriculture is fulfilled by the migrant laborers from Gorkha, Lamjung and nearby districts. Some of the skilled personnel work in Kathmandu and in Manang on a seasonal basis. 


\section{The Seasonality}

Seasonality is an important feature of mountain areas. This is more so in terms of people visiting mountain areas from outside. Seasonality in the flow of tourist arrival from 2002-2005 is discussed elsewhere (see Subedi, 2007). However, to recapitulate and update the situation, Table 4 presents the distribution of tourists by months in 2007. Obviously, tourism activity in Upper Manang is highly seasonal. There are two tourist seasons, namely spring and autumn. The three months, namely March, April and May form the core of the spring season. Of the total visitors, about 31 percent come during these three months with April alone sharing 15.7 percent of the total annual flow. The autumn season comprises September, October and November and is by far the main tourist season in Upper Manang. Nearly 60 percent of the total annual flow takes place in these three months. More importantly, October alone shares more than one-third of the total annual flow there.

\begin{tabular}{|l|r|r|}
\hline \multirow{2}{*}{ Months } & \multicolumn{2}{|c|}{ Tourist Arrival, 2007 } \\
\cline { 2 - 3 } & Number & Percent \\
\hline January & 116 & 0.8 \\
\hline February & 270 & 1.9 \\
\hline March & 1485 & 10.5 \\
\hline April & 2229 & 15.7 \\
\hline May & 674 & 4.7 \\
\hline June & 136 & 1.0 \\
\hline July & 175 & 1.2 \\
\hline August & 300 & 2.1 \\
\hline September & 1250 & 8.8 \\
\hline October & 4810 & 33.9 \\
\hline November & 2339 & 16.5 \\
\hline December & 408 & 2.9 \\
\hline Total & 14192 & 100 \\
\hline
\end{tabular}

Table 4: Tourist arrival by months in Upper Manang, 2007

Source: ACAP's local office in Manang.

Despite large concentration of tourists in two seasons, there were visitors in all twelve months in Upper Manang. January was recorded to have the least number of visitors. The other months with the least number of tourist arrivals are June, July, February, August and December, respectively. These high tourist arrival months also coincide with major agricultural activities (see also Subedi, 2004). Agricultural activities such as ploughing, sowing/planting takes place from the last week of March to the first and second week of April, and harvesting takes 
place during a fixed period from the last week of September to the first week of October in the valley.

\section{NATIONALITY AND SOME DEMOGRAPHIC CHARACTERISTICS OF TOURISTS}

\section{Tourist Nationality:}

Records available from the local ACAP office in Manang suggest that tourists from more than 64 countries visited Upper Manang in 2007. French citizens ranked highest. One out of every six visitors was French. They were followed by Israelis with their share of 13.5 percent. This ranking is a bit different from that of the 2002/03 record available from Humde which showed Israelis ranking highest with 19.6 percent followed by French with 16.4 percent (see Subedi, 2007). Germans ranked third and contributed about 12 percent to the total tourist arrival there. Britons ranked fourth. Both these rankings, i.e. third and fourth, are akin to that of 2002/03 figures. The other nationalities with their share of more than 3.0 percent include Americans, Australians, Dutch, Spanish and Canadians. Together, these nine nationalities shared almost 75 percent of the tourist flow in Upper Manang in 2007 (Table 5).

\begin{tabular}{|l|r|r|r|}
\hline \multirow{2}{*}{ Country of Origin } & \multicolumn{3}{|c|}{ Tourist Arrival } \\
\cline { 2 - 4 } & \multicolumn{1}{|c|}{ Number } & \multicolumn{1}{c|}{ Percent } & \multicolumn{1}{c|}{$\begin{array}{c}\text { Cumulative } \\
\text { percent }\end{array}$} \\
\hline France & 2378 & 16.8 & 16.8 \\
\hline Israel & 1909 & 13.5 & 30.3 \\
\hline Germany & 1672 & 11.8 & 42.0 \\
\hline United Kingdom & 1290 & 9.1 & 51.1 \\
\hline United States & 840 & 5.9 & 57.0 \\
\hline Australia & 780 & 5.5 & 62.5 \\
\hline Holland & 626 & 4.4 & 67.0 \\
\hline Spain & 546 & 3.9 & 70.8 \\
\hline Canada & 519 & 3.7 & 74.5 \\
\hline Switzerland & 397 & 2.8 & 77.3 \\
\hline Belgium & 303 & 2.1 & 79.4 \\
\hline Czech Rep & 297 & 2.1 & 81.5 \\
\hline South Korea & 277 & 2.0 & 83.4 \\
\hline Austria & 232 & 1.6 & 85.1 \\
\hline Poland & 224 & 1.6 & 86.7 \\
\hline Other Countries & 1902 & 13.3 & 100 \\
\hline Total & 14192 & 100 & - \\
\hline
\end{tabular}

Table 5: Tourists by their nationalities, 2007

Source: Compiled from ACAP's local office in Manang. 
As elsewhere in the country, Europeans and North Americans are the main tourists in this area. Usually, tourists who complete the Annapurna Circuit spend two to three nights in Upper Manang. According to local hotel owners, visitors spend one night at Pisang and the remaining two nights at Manang village.

\section{Tourist Demographic Characteristics:}

For analysis of demographic characteristics of tourists, such as sex and age, characteristics are based on 12 months' record of visitors passing through Humde Police Check Post from December 2002 to November 2003. Other published records lack such details. This record misses those trekking through alternative route to Manang village via Ghyaru-Ngawal without passing through the check post. However, the missing figures are small and moreover, the demographic characteristics are not expected to be different from the ones represented by the available records of Humde Post.

Sex selectivity is evident with males dominating the total flow of tourists in Manang. Of the total 7,492 tourists recorded in Humde, 62.4 percent were male and 37.6 percent female. The numerical dominance of male over female in the tourist arrival to Upper Manang remains the same for all twelve months (Table 6). A general tendency of higher sex ratio during lean months and relatively lower ratio during peak months is apparent. Of all the months, the number of female tourists is the highest in October and November.

\begin{tabular}{|c|c|c|c|c|c|}
\hline \multicolumn{2}{|c|}{ Months } & Male & Female & Total & Sex ratio \\
\hline \multicolumn{2}{|l|}{ December } & 123 & 70 & 193 & 175.7 \\
\hline \multicolumn{2}{|l|}{ January } & 43 & 16 & 59 & 268.8 \\
\hline \multicolumn{2}{|l|}{ February } & 115 & 70 & 185 & 164.3 \\
\hline \multicolumn{2}{|l|}{ March } & 354 & 239 & 593 & 148.1 \\
\hline \multicolumn{2}{|l|}{ April } & 791 & 407 & 1198 & 194.3 \\
\hline \multicolumn{2}{|l|}{ May } & 376 & 200 & 576 & 188.0 \\
\hline \multicolumn{2}{|l|}{ June } & 83 & 45 & 128 & 184.4 \\
\hline \multicolumn{2}{|l|}{ July } & 59 & 37 & 96 & 159.5 \\
\hline \multicolumn{2}{|l|}{ August } & 86 & 68 & 154 & 126.5 \\
\hline \multicolumn{2}{|l|}{ September } & 233 & 145 & 378 & 160.7 \\
\hline \multicolumn{2}{|l|}{ October } & 1522 & 940 & 2462 & 161.9 \\
\hline \multicolumn{2}{|l|}{ November } & 893 & 577 & 1470 & 154.8 \\
\hline \multirow[t]{2}{*}{ Total } & No. & 4678 & 2814 & 7492 & 166.2 \\
\hline & $\%$ & 62.4 & 37.6 & 100 & \\
\hline
\end{tabular}

Table 6: Tourist arrival by sex and by months in Upper Manang (Dec 2002-Nov 2003) 
Note: The figure for December refers to December 2002. Data for the rest of the months refer to 2003.

Source: Compiled from the record of Humde Police Check Post, Manang.

\section{Tourist Age-Sex Distribution:}

The number of tourists visiting Upper Manang is age selective. The largest proportion belongs to the 20-30 years age group. In terms of specific age groups, the 25-29 years age group claims the largest proportion. The age group of 20-24 years comes next. Together, these two groups constituted 44.4 percent of the total tourist flow in Upper Manang. The age group of 30-34 years contributed 18.1 percent. These three groups combined contributed 62.5 percent (Figure 3). In all these three age groups, males far outnumber females. The share of age groups below 20 years and those 60 years and above are very small. Thus, overall young adults dominate the total figure.

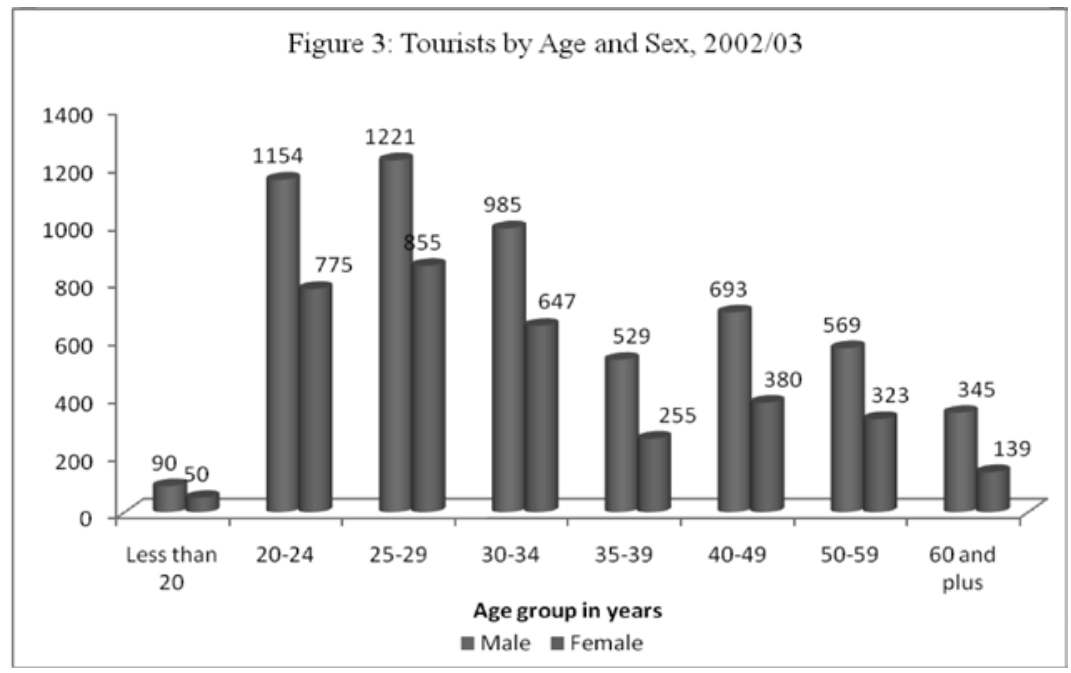

Source: Compiled from the record of Humde Police Check Post, Manang.

It is likely that this age selectivity has to do with adventure tourism in the high mountain areas. Normally those visiting Upper Manang intend to cross ThorungLa pass $(5,416 \mathrm{~m}$ asl), one of the highest mountain passes of the world.

\section{Conclusions}

Upper Manang is a special case of trekking tourism in Nepal. Since the 1980s, it has been able to attract more than 10,000 trekkers annually and the number is increasing in recent years. Even during the years of conflict, the number of visitors did not go down from 9,300 per year. With the increase in number of visitors, a parallel growth in the number of hotels have taken place and it is the 
residents of Upper Manang that are running the tourism business in the valley with their connection in the capital.

The role of tourism for national development cannot be exaggerated in Nepal. The scope of adventure tourism and green tourism have been increasing over time. The Annapurna Circuit is a unique and one of the best trekking routes in the world for the unique diversity from geographical, biological, climatic, cultural and social aspects. It is the area where which has demonstrated the success of conservation along with local development by involving local people.

With the increasing number of tourists in the region, some challenges have also emerged. The issue of mass tourism versus quality tourism becomes a concern when the number of tourists increases rapidly in such a small valley. Likewise, the issue of sustainability of tourism development is of prime concern and has already been noted in rural tourism destinations of developing countries (Nepal, 2008). In the meantime, there has been an increasing demand of infrastructure development such as road linking this area with Besisahar and the south. Whether motorable road linking Upper Manang with the south is good for tourism development and prolongation of tourist stay in this area is debatable, let alone environmental effects of such activities in the overall pristine landscape of the area. The Besisahar-Chame-Upper Manang road, which is under construction, is a case in point. It mainly follows the existing trekking route and has already compromised the trekking attraction of the route. The search of alternative route and the diversity of tourism products in the villages are essential for extending the length of stay of tourists. Climate change and receding glacier, abandoned agricultural fields and deserted households in most of the settlements are also major concerns for the sustainable development of tourism in the region.

\section{References}

Chapagain, P.S. 2008. Land, Labour and Agricultural Change in Upper Manang Valley: Understanding Meanings and Processes. Unpublished Ph. D Dissertation Submitted to FoHSS Dean's Office, Tribhuvan University, Kathmandu.

Cooke, M. T. 1985. The People of Nyishand: Identity, Tradition and Change in the Nepaltibet Borderland. PhD Dissertation, Department of Anthropology, University of California.

Gurung, G. 1995. Indigenous resource management system of Manang village in North Central Nepal: A case study and a project proposal. Kathmandu: KMTNC/ACAP.

Ives, J. D. 2006. Himalayan perception: Environmental Change and the well-being of mountain peoples (second ed.). Lalitpur: Himalayan Association for Advancement of Science.

Kawakita, j. 1957. Ethno-geographical Observations on the Nepal Himalayas, $\underline{\text { In People of }}$ Nepal Himalaya: Scientific Results of Japanese Expeditions to Nepal Himalaya 1952-53, edited by H. Kihara, Kyoto: Fauna and Flora Society, Kyoto University. 
King Mahendra Trust for Nature Conservation (KMTNC).1997. Annapurna Conservation Area Management Plan. Kathmandu:KMTNC.

KMTNC. 2005. Annual progress report 2004/05. Manang: King Mahendra Trust for Nature Conservation/Annapurna Conservation Area Project.

Koirala, T. P. 1981. Manang yek parichaya. Kathmandu: Royal Nepal Academy.

Ministry of Culture, Tourism and Civil Aviation (MCTCA). Nepal Tourism Statistics, 2006. Kathmandu: Ministry of Culture, Tourism and Civil Aviation, GoN.

Morimoto, I. 2007. The development of local entrepreneurship: A case study of a tourist area, Thamel in Kathmandu. In H. Ishii, D. N. Gellner, \& N. Katsuo (Eds.), Social dynamics in Northern South Asia : Nepalese inside and outside Nepal (Vol. I, pp. 351-382). New Delhi: Manohar Publishers \& Distributers.

Nepal, S. K. 2008. Tourism-induced Rural Energy Consumption in the Annapurna Region of Nepal. Tourism Management, 29: 89-100.

Van Spengen, W. 1987. The Nyshangba of Manang: Geographical Perspective on the Rise of a Nepalese Trading Community. Kailash, 13 (3-4): 131-277.

Parish, R. 2002. Mountain environments. Harlow: Pearson Education Limited.

Sharma, P. 1989. Assessment of Critical Issues and Options in Mountain Tourism in Nepal. Kathmandu: ICIMOD.

Subedi, B.P. 2007. Migration and Tourism in the Trans-Himalayan Region: Studies on Changing Livelihood Patterns of Upper Manang Community in Nepal. In Local Effects of Large Scale Global Changes: A Case Study in the Nepal Himalayas edited by Tor H. Aase, Ram P. Chaudhary, O. R. Vetaas and Bhim P. Subedi, Kathmandu: Tribhuvan University, Nepal and University of Bergen, Norway, pp.41-63.

2004. "Prasanga Upallo Manangko: Kura Manangko Bhaugolik Vishistatako" (Journey Around Upper Manang: Discussion of Geographic Uniqueness of Manang. Nepal Bhugol Patrika (a Nepali publication of Nepal Geographical Society) 1:22-26.

Watkins, J. C. 1996. Spirited women: Gender, religion and cultural identity in the Nepal Himalaya. New York: Columbia University Press. 